\title{
Four Decades of Advances in General Surgery at a Spanish Community Hospital
}

\author{
Aniceto Baltasar, Carlos Serra, Marcelo Bengochea, Carlos Escrivá, Emilio Marcote, Rafael \\ Bou, Javier Miró, Francisco Arlandis, Lirios Ferri, Luis Cipagauta, Nieves Pérez, Mario \\ Alonso, Rosa Martínez \\ Alcoy Hospital, Alcoy, Spain \\ *Corresponding Author: Aniceto Baltasar, Alcoy Hospital, Alcoy. Spain. baltasarani@ gmail.com
}

\begin{abstract}
Changes in the practice of surgery over the last 40 years have been extraordinary. We want to reflect the progress during this period in the Community Hospital of Alcoy, Spain. Technology and staff training have improved in an extraordinary way allowing that medical assistance in the community hospitals is quite similar to that offered at the most sophisticated centers.
\end{abstract}

Keywords: Advances in surgery; General Surgery; Community hospital.

Abbreviations:

1eu First in Europe

1st First in Spain

1w First in the world

ACS American College of Surgeons

\section{INTRODUCTION}

The changes in medicine with the creation in 1967 of the National Health System (NHS) in Spain and the Intern and Residents training (IRT) system have been extraordinary. The NHS hospitals network covers medium-sized cities with Community Hospitals $(\mathrm{CH})$ of less than 300 beds and 250,000 inhabitants'. Surgical improvements have been developed in recent years at University centers and similar ones are occurring at the $\mathrm{CH}$ level that are rarely reported but where the quality of the service is essential to serve the population.

\section{AIM}

Reflect the changes and advances in general surgery at a $\mathrm{CH}$ during a 40 years period.

\section{GEOGRAPHICAL AND HISTORICAL CONTEXT}

Alcoy with 60,000 inhabitants, and its health department with 140,000 persons in Southeastern Spain was first served by a magnificent Oliver Civil Hospital donated by a patron in 1868-77, but then faded with time and reflects what happened in other Spanish regions. The city, isolated, is located in mountainous area of the Valencia Region $60 \mathrm{~km}$ far from Alicante and $100 \mathrm{~km}$ from Valencia.

Alcoy $\mathrm{CH}$ was the first Community hospital of the Valencia Region and it was inaugurated in 1972 but the Head of Surgical Service was not appointed until 1974. The training of first IRT residents started in Spain in 1967 and graduated five years later, but many were not attracted to work in a supposedly "distant hospital" far from large centers and big cities, where the endowments were initially precarious. But by 1978 in Alcoy there were five IRT surgeons, and the coverage of other services took four more years to provide minimal services.

\section{The Dark Years 1974-78}

Aniceto Baltasar MD (AB) was appointed in 1974 as Head of Service and started working alone with only one assistant (J. Tomas MD) until 1978. Later on, 7 non specialist fellows (Del Rio, Bou, Fernández, Aracil, Pérez, Carbonell and Llopis) gave us an invaluable support. We opened an Intensive Care Unit (ICU) in 1976 with 3 beds, two pressure and three volumetric ventilators, monitors, PVC, 
hypothermia blankets, anti-scar mattresses, gas analyzer, cardio conversion and pacemakers. Twelve young nurses were trained with daily classes and the translation of two books on Ventilator and Cardiac Care [1,2]

We abandoned the traditional cut-down venotomies in favor of the subclavian punctures and initiated the use of complex procedures (aortic grafts, femoro-popliteal bypasses, Swiss AEO osteo-synthesis, 52 transverse and Seldinger angiographies (52), bronchoscopies (45), intra-cavitary and epicardial pacemakers (46), lung lobectomies, Comando mandible resection, fibro-gastroscopy (28), mid-sternal thoracotomy for mediastinal tumor, porto-cava shunts, Nyhus pre-peritoneal hernia and pancreatectomies.

The Alcoy's Analysis and Blood Bank Services (a magnificent volunteer institution) were excellent, with all necessary blood transfusions but $\mathrm{w}$ derivatives at the time.

\section{Years 78-90. Open Surgery}

Then in 1978 the four first IRT well trained surgeons (Bengochea, Del Río, Marcote, Escrivá) and by 1987 two more, Bou and Miró, joint us members of the staff. Later on Arlandis and Alonso arrived in 1990, and Serra (current Chief of the Service), Martínez and Cipagauta in 1992 (Fig.1), and by then the surgical team with 11 members was considered complete (Fig. 1).

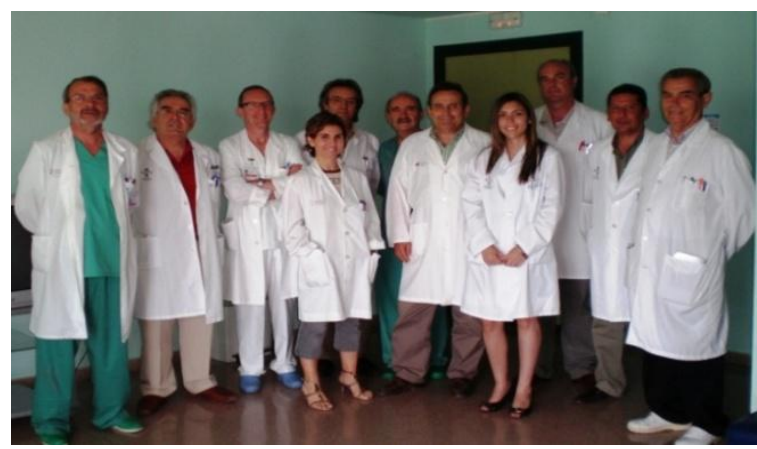

Fig1. Alcoy CH Surgical staff

By 1985 other services staffs (Anesthesia, Radiology, Digestive-endoscopies, ICU, Pathology) were filled. In 40 years the Surgical Service have been very fortunate to have an stable staff since only three members left the service to occupy relevant positions in other hospitals and by 1998 obtained the IRT teaching position of one resident per year, and has become an organ donor center, has MRI and an oncology service with radiotherapy.

\section{Colostomy Irrigation}

In 1983 we founded Alcoy Ostomy Club (AOC) and Spanish Ostomy Club (SOC) and organized three meetings in Alcoy. We started colostomy irrigations in Spain [3], a very uncommon therapy and published two videos [4], and a paper with permission from the Mayo Clinic of Rochester, MN [5]. In this volunteer program a patient with a colostomy visits patients in the pre and postoperative period and shows them what a colostomy is. He teaches the patient and his family the technique of colostomy lavage before discharge and the use of a plugging device that allows him to live "without using a colostomy bag", as a normal person without any psychological traumas, to participate in social events and even to bathe in public swimming pools. All the patients have performed their irrigation every two days for years. Ms. Encarna Nadal has been teaching and caring for all patients with ostomies for 30 years and participated in two National TV programs to publicize the irrigation and received recognition awards by the Alcoy $\mathrm{CH}$ in November 1995 and the Rotary Club Alcoy in 2016 for his disinterested dedication.

\section{Vascular Surgery}

In the years 1970-80 there were no Vascular Surgery Units in the country but this surgery was performed in many hospitals. We started in the country the $1^{\text {st }}$ use of Inahara [6] technique of eversion retrograde thrombo-endarterectomy (ERTE) that had better results than the vascular grafts. We introduced the technique in National Surgical and Vascular Surgery Congresses. An ERTE video [7] received the Motril Aesculapius Award in 1984, the most important in Spain at that time. We started the use of "Sparks grafts", an ingenious attempt to "create vessels" [8], but without long-term success, since progressive fibrosis of the grafts finally obstructed the vessels.

Major infra-abdominal aorta major surgery, mesenteric vessels, iliac, femoro-popliteal bypass, carotid aneurysms were carried out. Unilateral ERTE from aortic bifurcation to the femoral bifurcation were the most frequent under regional anesthesia. 


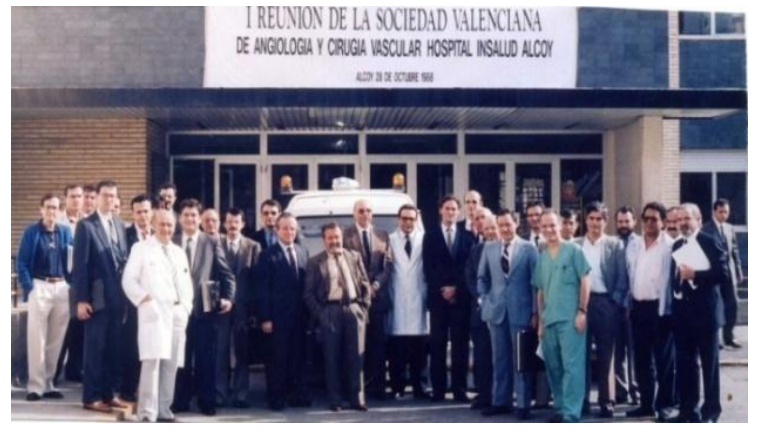

Fig2. 1st Valencia Vascular meeting 1988

The Valencia Vascular Surgery Society $1^{\text {st }}$ Meeting was held in Alcoy in October 1988, attended by Juan Matesanz, a distinguished Boston-trained surgeon and $1^{\text {st }}$ chief of the Madrid Vascular Clinic at the University Hospital (Fig. 2).

We reported on aortic aneurysms [9], internal carotid aneurysm [10,11], combined aortoiliac and double bowel revascularization [12], venous aneurysm [13] and anastomotic aneurysm [14]. The Vascular Services in the Valencia community started working and in 1998 and then we abandoned this surgery.

\section{Vascular and Oncologic Surgery}

Nine cases of radical oncology and vascular resection were done. The $1^{\text {st }}$ in 1985 was a sarcoma in the middle third of the right thigh including the femoral vessels. A radical resection of the tumor and vascular reconstruction (arterial with Dacron, femoral veins with two inverted saphenous vein grafts, and the formation of arterial-venous fistula at the ankle to prevent thrombosis of the veins) was done and this patient currently lives [15].

In 1982, a patient had a recurrent retroperitoneum metastatic disgerminoma involving the infra-renal aorta wall. She had a radical left nephrectomy and infra-renal aortic resection. A Dacron aortic graft was used to reconstruct the aorta, and is currently living [16]. Until then, only one case of aortic resection and vena cava had been published by Crawford and De Bakey [17], 7 cases of 297 sarcomas by Fortner [18] from the NYC Memorial and 13 cases by Imparato [19] at Roswell Park in Buffalo, NY, both recognized global centers dedicated to cancer.

We then performed four infra-renal aortic resections for retroperitoneal sarcomas [20] and presented a video at the ACS American Congress in Chicago at the Symposium
"Spectacular Problems in Surgery" [21] an unusual technique at that time. And the ACS requested to present it again eight years later and it was done by Dr. Serra in San Francisco and is in ACS Video Library.

One of those resected sarcomas recurred at the left iliac vein 2 years later and the left iliacfemoral (left artery and vein) were resected [22], and had a cross-femoral revascularization with two saphenous (for artery and vein) were done. He suffered massive hemorrhage from pelvic veins and was treated with abdominal packing. He remained intubated at the ICU and was reoperated three days later, the pelvis was clean and the abdomen was closed, and both crossfemoral grafts remained permeable.

\section{Thoracic Surgery}

From the beginning, we performed thoracic surgeries such as bronchoscopies (from 40 to 68 per year), tracheotomies (8-12), thoracoscopy, pneumothorax (12-15), lobectomies and pneumonectomies for cancer (7-11), esophagus (9) and endocavitary pacemakers. We introduced thoracoscopy in 1993 and performed bilateral sympathectomies for hyperhidrosis, emphysematous bullae [23], neurilenoma [24] and the $1^{\text {st }}$ pericardial window due to effusion in the country [25]. In 2003 all thoracic surgery was transferred to the newly created regional referral center.

Neck

We did treated thyroid and parathyroid tumors, radical neck dissections [26], parotid tumors [27], two rare cases of suffocating retropharyngeal cervical lipomas $[28,29]$ and radical surgery for cervical esophagus cancer with gastroplasty [30]. Four esophageal lesions [31] due to autolysis with Salfumant were operated with immediate resection of the esophagus and stomach and then colonic transposition. One patient required later a dermocutaneous plastic surgery graft from the arm skin to form a tube to treat a residual pharyngeal stenosis, with good functional results. Two of these patients have colonoplasty to the oropharinx and then developed stenosis in the hypopharynx that required re-operations by the Service of Plastic Surgery of Bellvitge, Barcelona [32] with dermo-cutaneous vascularized forearm free flaps. The donor skin was covered with skin graft from the thigh (Fig. 3). 

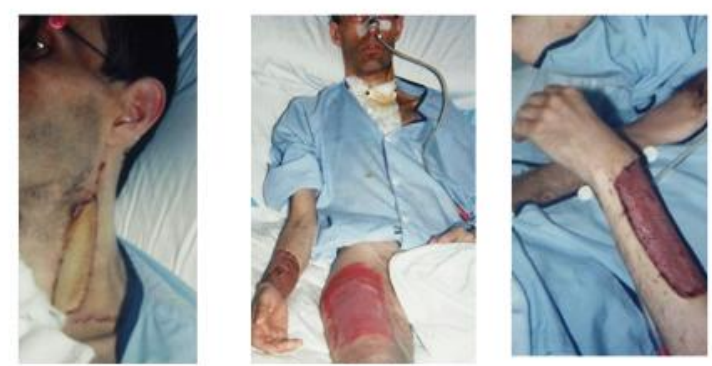

Case 1 Neckgraft. Right thigh donor skin.

Right arm vasculo-dermoc utanous gratf
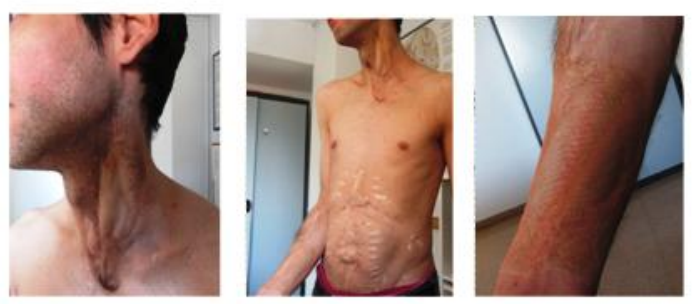

Case 2. Neck graft. Abdomen laparo tomy scars. Right arm vasculo-cutaneus graft

Fig3. Dermocutaneous grafts to make upper cervical eophagus

Breast Surgery

The Services of Surgery and Radiology began in 1994 the $1^{\text {st }}$ center for detection and screening of breast cancer in the Valencia community. We treated phyllodes tumors [32], breast carcinosarcoma [33] and mammary reconstructions with immediate prostheses [34].

Marcote [35] published DNA ploidy and Sphase of the cell cycle and active proliferation in 104 patients, flow fuidmetry in 220 patients [3637] and was Ph.D. "Cum Laude" award in 1990. Serra (38-43) also published in 1990 extensive studies of male breast cancer with determination of the Pepsinogen C and Apolipoprotein D. He received a Ph.D. "Cum Laude" award.

\section{Digestive Surgery in the 80 's}

The $1^{\text {st }}$ two cases of Kock's continent ileostomy were done in 1985 after total colectomy for diffuse colonic cancer [44-45]. A Kock double valve urinary continent ileostomy [46] was done in a patient with single kidney and recurrent bladder cancer. We published several surgical corrections of post-traumatic diaphragmatic hernias [47-52].

In the 1980s, gastro-duodenal ulcers were a very prevalent condition and we used VARY (vagotomy-antrectomy and Y-de-Roux reconstruction) [53,54] in 67 patients with very good results between 1978-85. Two patients suffered mesenteric necrosis, one 11 years later due to mesenteric rotation and another 4 years later [55].

Martínez [56-58] in 1994 obtains her Ph.D. "Cum Laude" for studies on gastric emptying after gastritis of reflux, VARY and duodenal switches. We used sphincteroplasty [59,60] according to Austin Jones [61] in 67 cases with bile duct obstruction of 558 gallbladder operations with a mortality rate of $1.5 \%$.

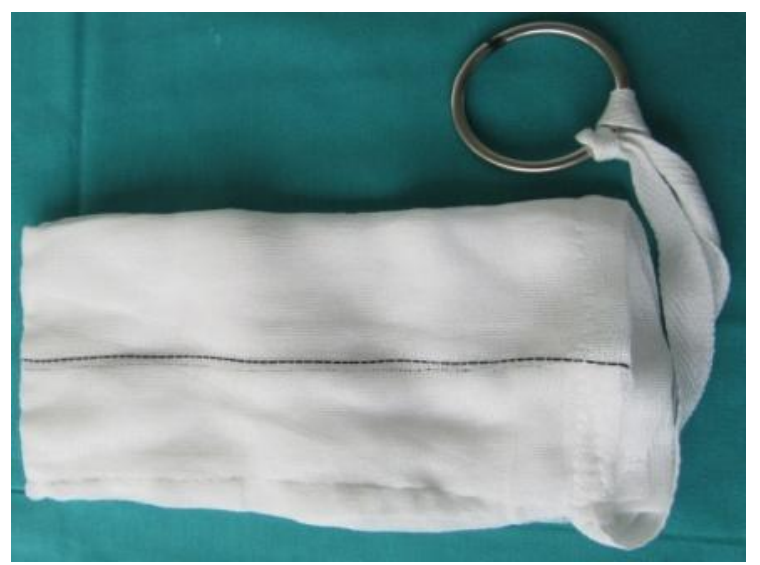

Fig4. Lap-pad with ring to avoid forgotten foreign bodies in chest and abdomen

We performed in 1980 the $1^{\text {st }}$ cephalic pyloruspreserving in pancreatectomy in Spain [62, 63], with a continuous monoplane posterior pancreato-gastrostomies not usual at the time.

In 1989 we initiated the duodenal preservation in cephalic resection of pancreas by chronic pancreatitis [64] according to Beger [65]. A video, the first presented [66] at the ACS in Chicago 2006 is on ACS video library and Martínez [67] made a review of four cases.

Retained foreign bodies in the abdomen are an unpleasant complication and we used compresses with rings $[68,69]$ as very effective to avoid them and no patient suffered this complication in 40 years (Fig.4).

Continuous sutures were done in abdominal closures and in digestive anastomosis [70, 71], and Serra [72] used the $1^{\text {st }}$ Spanish selfexpanding prostheses in colonic obstructions. Pardo JL [73] publishes in 1996 (Fig.5) the "Index of authors who publish the most" in Spanish Surgery. And Alcoy-CH ranks $1^{\text {st }}$ among $\mathrm{CH}$ and $7^{\text {th }}$ since $1973-93$ among all the country hospitals and the $1^{\text {st }}$ of all in June 1996. 
TABLA 3. Relación de grandes productores de Cirugía EsPañola entre 1974 y $1993($ Ip $>1,5)$

\begin{tabular}{lc}
\hline \multicolumn{1}{c}{ Autor } & N. ${ }^{*}$ de artícul \\
\hline Parrilla Paricio, P. & 155 \\
Balibrea Cantero, J.L. & 79 \\
Sánchez Bueno, F. & 68 \\
Ponce Marco, J.L. & 66 \\
Gómez Alonso, A. & 53 \\
Aguayo Albasini, J.L. & 51 \\
Moreno González, E. & 49 \\
Narbona Arnau, B. & 47 \\
González González, M. & 46 \\
Baltasar Torrejón, A. & 43 \\
Marcote Valdivieso, E. & 42 \\
Lozano Mantecón, R. & 41 \\
Carbonell Antolí, C. & 41 \\
$\quad$ Fig5. List of producers in Cir. Esp 1997
\end{tabular}

\section{Laparoscopic Surgery 1992}

Starting in 1992 laparoscopy has been the biggest surgery revolution in these forty years. We were spectator in the $1^{\text {st }}$ laparoscopic gallbladder at the Ruber International Sanatorium in Madrid in 1990. We started our $1^{\text {st }}$ gallbladder by lap in 1991, oophorectomy in1992, resection of lung bullae in 1992. mediastinal tumor in 1992, pulmonary tuberculosis in 1994, splenic rupture in 1994. Pericardial window in 1994. Nissen - 1996. Splenectomy - 1996. Inguinal hernia - 1997. Left colectomy -1997. TAPP - 1997. TEP 1998. Colectomy - 1998. Adrenalectomy-1998. Heller-1998. Abdominoperineal-1999. Thoracic sympathectomy-2000. Use of intra-abdominal meshes after a visit to Dr Carbajo - 2000. Currently the service perform standard intraabdominal laparoscopy and the "laparoscopic" group does colon, adrenal, spleen, abdominoperineal resections, noninvasive endoanal resection and distal pancreatectomies.

\section{Bariatric Surgery (Bs)}

Alcoy- $\mathrm{CH}$ is recognized internationally as a pioneer bariatric center [74]. AB funded Spanish Society for Obesity Surgery (SECO) in 1997, the BMI-Latin magazine (www.bmilatina.com) in 2011 and became President of the International Federation for the Surgery of Obesity (IFSO) and organizer of $8^{\text {th }}$ IFSO World Congress in 2003. We cofounded the European Centers of Excellence in 2013, performed in 1977 the $1^{\text {sp }}$ Roux-en-Y gastric bypass (RYGBP) [75], $1^{\text {sp }}$ metabolic surgery (MS) for hyper cholesterolemia [76], $1^{\mathrm{w}}$ separation of the vertical line in the Vertical Banded Gastroplasty $(V B G)[77,78], 1^{\text {sp }}$ open Duodenal Switch (DS) in 1995 [79], $1^{\mathrm{eu}}$ lap RYGBP in Europe (LRYGBP) 1977 [80,81] and $1^{\mathrm{w}}$ report of internal hernias after LRYGBP [82], $1^{\text {eu }}$ laparoscopic DS (LDS) [83] in 2001. The paper on Sleeve Gastrectomy was one of the $1^{\mathrm{eu}}$ in Europe [84] has the $61^{\text {st }}$ higher bariatric citation index in the world [85]. Non-removable Wall-stents for leaks $[86,87]$ were used in 2000 before the removable ones were developed, performed the $1^{\mathrm{w}} R N Y$ diversion for SG leaks $[88], 1^{\mathrm{sp}}$ diabetes surgery $2004[89], 1^{\mathrm{sp}}$ and adolescent bariatric surgery (ABS) 2008 [90] and developed the concept of Expected BMI (Body Mass Index) after Bariatric Surgery [91].

\section{ASSOCIATIONS AND CONGRESSES}

- Founders Video-Revista de Cirugía (VRC) with Dr Ballesta-1987 in four languages (French, Italian Spanish and Portuguese)

- Founder of the European Association of Video Surgery. 1988

- Organizer of the I National Congress of Video Surgery. Alcoy-Alicante 1989.

- For 20 years (1987-2007) organized yearly the Alicante Province Meetings of Surgery

- 1984-2004 Detailed Memories (Annual Reports) of the Service.

- Posters. 46. Two first prizes Milan 1994 and Valencia SECO 2010

- Videos: The HC-Alcoy has published 25 videos in VRC. 101 in Spanish-. 3 first Prizes and 12 winners in Videomed and VideoSurgery Valencia 44 in English-. 2 First prizes and 3 more prizes http://www.youtube.com/channel/UCEpwVh QEohunxKOhNqC71zg

- 283 articles published in general surgery and 109 in bariatric. Research Gate: Maximum number of citations in the province of Alicante with Publication downloads 10,878. Views 8, 631, 1.99 per publication, 1,154 citations

\section{REFERENCES}

[1] Bean S, Brown N, Chey A.: Physiologic bases for respiratory care. Mountain Pres Publishing Co. Missoula, MT.1977

[2] Hamilton A.: Selected subjects for critical care nurses. Mountain Pres Publishing Co. Missoula, MT.1978

[3] Baltasar A, Del Río J, Herrera GR.: Irrigación de las colostomías. Boletín de la AEC (Asociación española de ostomizados) 1984; 1:1-3.

[4] Baltasar A, Del Río J, Herrera GR: Colostomy washouts. $\quad$ VRC 1984;1: 10-11. www.youtube.com/watch?v=Pjn1HtEAl1M\&ww w.youtube.com/watch?v=dq-wIU4nCUE 
[5] Baltasar A, Jao S, Beart R. et al: Cuidados de irrigación en las colostomías sigmoideas. Arch Surg 1985; 120:916-7. Una traducción autorizada del artículo de la Clínica Mayo en Cir Esp. de Jao y Beart R.

[6] Inahara T.: Endarterectomy for occlusive disease of the aorto-iliac common femoral arteries. Am J Sur 1972; 124:235

[7] Baltasar A, Herrera GR.: Tromboendarterectomía retrógrada aorto-femoral bilateral. VRC 1987: 4:1-4 http://youtu.be/5BYrlX19WNI

[8] Noël R, HP Thévenet HP, King A, Guidoin M.: The Sparks-Mandril arterial prosthesis. An ingenious concept, a total failure. What can we learn from it? Journal des Maladies Vasculaires 1984; 9:277-83

[9] Blanquer JJ, Rapa A, Adam A et al. Aneurismas de aorta. Atención primaria 1992; 10:916-9.

[10] Marcote E, Arlandis F, Baltasar A.et al. Aneurisma de carótica interna. Cir Esp 1993; 5:455-7.

[11] Baltasar A, Marcote E, Arlandis et al. Aneurisma de carótida interna. Video. VCR 1994; 11:15-24. https://youtu.be/IrD-Pj1cxFM

[12] Marcote E, Baltasar A, Arlandis F.: Revacularización combinada aortoiliaca e intestinal doble. CTV1991; 9:543-8.

[13] Marcote E, Arlandis F, Baltasar A: Aneurisma venoso primario de safena. CirEsp1994;55:440-1

[14] Marcote E, Arlandis F, Martínez R et al. Aneurisma anastomótico de arteria femoral. Cir Andaluza 1994; 5:52-56.

[15] Baltasar A, Escrivá C, Marcote E.: Un caso de cirugía vascular reconstructiva para salvar la extremidad inferior por sarcoma. Rev Quir Esp 1980; 7 (8): 326-330.

[16] Baltasar A, Marcote E, Barnés JJ, Bengochea M.: Resección de aorta abdominal por disgermino-ma retroperitoneal metastá-sico. CTV 1985: 5(4): 224-8.

[17] Crawford ES, De Bakey M.: Wide excision including involved aorta and vena cava and replacement with artic homograft for retroperitoneal malignant tumors. Cancer 1956; 9:1085

[18] Fortner JG, Kim DK, Shiu MH.: Limb-preserving vascular surgery for malignant tumors of the lower extremity. Arch Surg, 1977; 112:803.

[19] Imparato AM, Roses DF, Francis KC, Lewis MM.: Major reconstruction for limb salvage in patients with soft tissues and skeletal sarcoma of the extremities. Surg Gynec Obstet 1978; 147: 891-6

[20] Baltasar A, Arlandis F, Bou R. et al.: Reconstrucción vascular en la cirugía oncológica radical. Cir Esp 1995; 58:345-9.
[21] Martínez R, Arlandis F, Baltasar A et al. Reconstrucción vascular in retroperitoneal sarcomas I. VRC 1999; 16:15-17. www. youtube.com/watch? $v=456 \mathrm{EEEUZNHc}$

[22] Martínez R, Arlandis F, Baltasar A et al. Reconstrucción vascular in retroperitoneal sarcomas II. VRC 1999; 16:31-34. www.youtube.com/watch?v=6R6J6N90K3Q

[23] Baltasar A, Escrivá C, Bou R et al: Resección de bullas enfisematosas por toracoscopia. VCR 1993; 10:16-19. https://youtu.be/_d27SO2Xuf4

[24] Baltasar A, Miró J, Bou R et al: Resección por toracoscopia de Neurilenoma mediastínico. VCR 1994; 11:35-38.https://youtu.be/EQOhtlB8deQ

[25] Arlandis F, Baltasar A, Del Río et al: Creación de ventana pericardio-pleural por video toracoscopia. VCR 1995; 12 : 43-46. www.youtube.com/watch?v=_wCC2M2MNcE

[26] Arlandis F, Serra C, Baltasar A et al: Bilateral functional dissection of the neck. VCR 1997; 13:6-11 www.youtube.com/watch?v=cp12Ogofn5o

[27] Martínez R, Baltasar A, Serra C et al. Total parotidectomy preserving the facial nerve "Conservative parotidectomy). VCR 1997; 11:3539.www.youtube.com/watch?v=uYlo6ApLpu4

[28] Serra C, Baltasar A, Arlandis F et al: Suffocating retrophayngeal lipomas. VCR. 1997:14:7-13. https://youtu.be/NB1ZDNzlnAU

[29] Baltasar A, Nuñez R, Arlandis F, et al. Lipomas retrofaríngeos sofocantes. Cir Esp 1997; 62:516-8.

[30] Serra C, Baltasar A, Bou R et al. Radical surgery in cervical esophageal cancer. Cirugía radical en cancer de esófago cervical. VRC 1999; 14:3133. www.youtube.com/watch? $v=c p 12 O$ gofn5o

[31] Dewever M, Gomes T, Madrazo Z, Viñals JM.: Failure of colon interposition after esophagogastrectomy: what is the next step? Cir. Esp. February 2015: 93:119-120 DOI: 10.1016/j.ciresp.2014.10.001

[32] Serra C, Arlandis F, Martínez R, Baltasar A.et al. Lesiones faringo-esofágicas por ingestión de Salfumant. Cir Esp 1996;59:77-80

[33] Marcote E, Arlandis F, Baltasar A et al: Tumores phyllodes de mama. Cir Andaluza 1993; 10:42-48

[34] Martínez R, Baltasar A, Manzano et al.: Carcinosarcoma de mama. Cir Esp 1996; 60:5157

[35] Serra C, Arlandis F, Del Río J, Baltasar A. et al.: Reconstrucción inmediata con prótesis tras mastectomía en la enfermedad benigna y maligna de la mama. Cir Esp 1999: 65:130-4. Premio Videomed. https://youtu.be/VpQQfRjxv3c

[36] Marcote E, Campos A, Baltasar A. et al: Significación pronóstica de la ploidía del ADN y de la fase $\mathrm{S}$ en el cáncer de mama. Cir Esp 1993; 53:89-96 
[37] Marcote E, Campos A, Baltasar A. et al: Ploidy, proliferative activity and other prognostic factors in breast cancer. Research in Surgery 1993; 5:121-126.

[38] Marcote E, Campos A, Bauza et al.: The prognostic significance of DNA ploidy and Sphase in breast cancer. Research in Surgery. 1993; 5:184-188.

[39] Serra C, Martínez R, Cipagauta L et al.: Carcinoma de mama sincrónico bilateral en un paciente varón. Cir Esp 1995; 5:368-9

[40] Serra C, Vizoso F, Medrano J. et al. Estudio multicéntrico de 70 pacientes varones diagnosticados de cáncer de mama. Cir Esp 1998; 64:213-220.

[41] Serra C, Vizoso F, Rodriguez J et al.: Expression of Pepsinogen $\mathrm{C}$ in ginecomastias and male breast carcinomas. World J of Surg 1999; 23:239-445.

[42] Serra C, Vizoso F, Lamela ML. et el.: Expression and clinical significance of apolipoprotein D in male breast cancer and gynaecomastia. British Journal of surgery 1999; 86:1190-7

[43] Serra C, Vizoso F, Lamelas ML et al.: Comparative study of two androgen-induced markers (Apolipoprotein D and Pepsinogen C) in female and male breast cancer. Journal of surgical investigation. 2000; 3:183-192

[44] Quintela I, Vizoso F, Serra C, Baltasar A.: Inmuno-histochemical study of Pepsinogen $\mathrm{C}$ expression in cutaneous malignant melanoma: association with clinicopathological parameter s. Internatio-nal Journal of biological markers 2001: 4:240-4

[45] Baltasar A, Del Río J, Bengochea $\mathrm{M}$ et al: Ileostomía continente de Kock. VRC 1985; 2: 1213. https://youtu.be/dq-wIU4nCUE

[46] Bengochea M, Del Río J, Baltasar A.: Carcinomas múltiples de colon y recto. Rev. Quir Esp 1985; 12:122-125

[47] Alonso M, Baltasar A, Arlandis F et al. : Kock urinario. Válvula continente tras extirpación de vejiga urinaria.VCR 1988; 5: 17-32. www.youtube.com/watch?v=kN6VpJ6cF_k\&feat ure=youtu.be

[48] Baltasar A.: Hernia diafragmática postraumáti ca, con neumotórax completo por perforación colónica. Rev Cli Esp 1976;141:86-96

[49] Del Río J, Baltasar A, Herrera GB.: Hernia diafragmática postraumática. VCR 1984; 1:12-13

[50] Marcote E, Baltasar A.: Late presentation of posttraumatic diaphragmatic hernias. Chirurgie d'urgences 1990; 1:272-274.

[51] Marcote E, Baltasar A, Serrano M. et al. Rotura diafragmática traumática derecha. CTV 19; 9:3415.

[52] Arlandis F, Baltasar A, Marcote E et al.: Vólvulo gástrico que complica en hernia diafragmática incarcerada con deslizamiento. Cir Andaluza $1991 ; 6: 212-6$
[53] Martínez R, Baltasar A, Cipagauta L et al: Fomas de presentación tardía de la hernia diafragmática pos-traumática. Cir Es 1994; 6:477-80

[54] Baltasar A, Del Río J, Escrivá C. et al: Vagotomía troncular, gastrec-tomía parcial y reconstrucción con Y de Roux en el ulcus gastroduodenal. Cir Esp. 1987; 4:564-555.

[55] Baltasar A.: Ulcus gastroduodenal ¿VARY o Billroth-III? Video. VRC. 1988; 5:3. https://youtu.be/tUztNgvLFsE

[56] Baltasar A, Marcote E, Del Río J et al. Necrosis intestinal masiva tardía después de VARY: Billroth-III. Cir Esp 1995; 57:270-273.

[57] Martínez R, Pérez-Mateo M, Baltasar A et al.: Valor diagnóstico en el diagnóstico de la gastritis postoperatoria por reflujo alcalino. REEAD 1995; 87:564-8.

[58] Martínez R, Vidal V, Baltasar A et al: Nuevo método de estudio del vaciado gástrico en pacientes gastrectomizados. REEAD 1995; 97:769-73.

[59] Martínez R, Baltasar A, Vidal J.: Estudio del vaciado gástrico en pacientes con obesidad mórbida intervenidos por cruce duodenal. REEAD 1997; 89:413-4

[60] Baltasar A, Tomás J, Bengochea M.et al: Esfinteroplastia (no esfinterectomía) en patología biliar. Cir Esp 1986; 4:874-880.

[61] Baltasar A, Tomás J, Bengochea M.: Sphinteroplasty (no sphinterotomy) in biliary surgery. Video. VRC.1986; 3: 26-28. https://youtu.be/GbqZKL1D1qc

[62] Jones A.: Sphinteroplasty (no sphinterotomy) versus latero-latero choledoco-duodenostomy. Varco. Saunders. Philadelphia. 241-256.

[63] Baltasar A, Tomás J, Miralles. Preservación de píloro. Pancreato-gastrostomía posterior. REEAD. Junio 1983; 63: 507-512.

[64] Bengochea M, Baltasar A, Marcote E et al: Duodenopancreatectomía cefálica con preservación de píloro. Pancreato-gastrostomía posterior. VCR 1989; 6: 29-34. https://youtu.be/u3TSFifq07E

[65] Baltasar A, Marcote E, Del Río J. et al: Preservación duodenal en la resección cefálica de páncreas por pancreatitis crónica. Cir Esp. 1990; 2:225-232.

[66] Beger HG, Buchler M, Bottner $R$ et al. Duodenum-preserving resection of the head of the pancreas in severe chronic pancreatitis. Early and late results. Ann Surg 1988; 209: 273-278.

[67] Baltasar A. Duodenum-preserving cephalic pancreatectomy. Video. VCR 1992: 9:35-40

[68] Martínez R, Baltasar A, Del Río J, et al: Preservación duodenal en la pancreatectomía cefálica por pancreatitis crónica. Cir Esp 1996; 60:90-92 
https://www.youtube.com/watch?v=3OFHtStHS4

[69] Marcote E, Arlandis F, Baltasar A.: Cuerpo extraño textil olvidado en el abdomen. A propósito de dos casos. Cir Esp 1993; 54:181-4.

[70] Baltasar A, Marcote E, Arlandis F, et al. Cuerpos extraños olvidados en el abdomen. Una forma eficaz de detección. Cir Esp 1996; 60:150-1.

[71] Arlandis F, Baltasar A, Marcote E.: Cierre de laparotomías con sutura continúa reabsorbible monofilamento. Cir Andaluza 1992; 3:11-14

[72] Baltasar A, Del Río J, Marcote E.et al: Sutura continúa monoplano con poligluconato monofilar en anastomosis digestivas. Cir Esp 1993; 53:182185.

[73] Serra C, Bengochea M, Camps J et al.: Utilización de prótesis metálicas auto-expandibles en el tratamiento inicial de la neoplasias obstructivas del colon izquierdo. Cir Esp 1997; 62: 234-236

[74] Pardo JL, Sáez JM, Domingo P. et al: La productividad de loa autores nacionales de cirugía. Análisis bibliométrico a través de la revista Cirugía española en el periodo 1974-1993. Cir Esp 1993; 60:21-25

[75] Shikora S, Torres A. Biography: Aniceto Baltasar. Obes Surg 2016;26:477-8.

[76] Baltasar A, Del Río J, Bengochea M. Bypass gástrico en la obesidad mórbida. Rev Clín Española.1980; 157:395-9.

[77] Baltasar A, Marcote E, Bou R, et al. Exclusión ileal parcial en la hipercolesterinemia. Cir Esp. 1991; 49: 475-8.

[78] Baltasar A. Modified vertical gastroplasty: Technique with vertical division and serosal patch. Acta Chir Scand. 1989; 155: 107-12.

[79] Baltasar A, Bou R, Arlandis F, Martínez R, et al. Vertical banded gastroplasty at more than five years. Obes Surg. 1998; 8:29-34.

[80] Baltasar A, Bou R, Marcote E, et al. Hybrid bariatric surgery: Biliopancreatic diversion and duodenal switch. Obes Surg. 1995; 5:419-23.
[81] Baltasar A, Bou R, Bengochea M, Miró J, Arlandis F.: Lap Roux-Y gastric bypass. Obes Surg. 1998; 8:393.

[82] Baltasar A, Bou R, Miró J, et al. Laparoscopic gastric bypass. Bypass gástrico laparoscópico. Rev Esp Enferm Ap Dig. 2000;10:661-4.

[83] Serra C, Baltasar A. Internal hernias and gastric perforation after laparoscopic gastric bypass. Obes Surg. 1999; 9:546-9.

[84] Baltasar A. Bou R, Miro J, et al. Laparoscopic duodenal switch. Technique and initial experience. Obes Surg. 2001; 12:245-8.

[85] Baltasar A, Serra C, Pérez N, et al. Laparoscopic sleeve gastrectomy. A multi-purpose operation. Obes Surg. 2005; 15:1124-8.

[86] Ahmad SS, Ahmad SS, Kohl S. The Hundred Most Cited Articles in Bariatric Surgery. Obes Surg. 2015; 25:900-9.

[87] Baltasar A, Pérez N, Bou R, Miro J, Bengochea M, Arlandis F, Escrivá C, Serra C, Martínez R. Wall-stent prosthesis for severe leak and obstruction of the duodenal switch Gastric tube. Obes Surg. 2000; 10:309.

[88] Serra C, Baltasar A, Andreo L, et al. Treatment of gastric leaks with coated self-expanding stents after sleeve gastrectomy. Obes Surg. 2007; 17:866-2.

[89] Baltasar A, Bou R, Bengochea M, et al. Use of a Roux limb to correct esophagogastric junction fistulas after sleeve gastrectomy. Obes Surg. 2007; 17:1409-10.

[90] Baltasar A.: Historical note: First diabetes metabolic operation in Spain. Integr Obesity Diabetes, 2015; 2(1): 180-182. doi: 10.15761/IOD.1000140

[91] Baltasar A, Serra C, Bou R, et al. Sleeve gastrectomy in a 10-year-old child. Obes Surg. 2008; 18:33-6.

[92] Baltasar A, Pérez N, Serra C, Bou R, Bengochea M, Borrás F. Weight loss reporting: Predicted BMI after bariatric surgery. Obes Surg. 2011; 212:367-72.

Citation: Baltasar A, Serra C, Bengochea $M$ et al. Four Decades of Advances in General Surgery at a Spanish Community Hospital. International Journal of Research Studies in Medical and Health Sciences. 2017;2(3):27-34

Copyright: (C) 2017 Baltasar A, et al. This is an open-access article distributed under the terms of the Creative Commons Attribution License, which permits unrestricted use, distribution, and reproduction in any medium, provided the original author and source are credited. 